\title{
PENERAPAN MODEL PROBLEM BASED LEARNING MELALUI APLIKASI WHATSAPP GROUP DALAM PEMBELAJARAN BIOLOGI UNTUK MENINGKATKAN HASIL BELAJAR DAN AKTIVITAS SISWA
}

\author{
I GEDE PUTU SUARDIKA \\ SMAN 1 Manggis, Karangasem Bali \\ Email : g71.suardika@gmail.com
}

\begin{abstract}
ABSTRAK
Penelitian tindakan kelas ini bertujuan untuk meningkatkan hasil belajar dan aktivitas siswa kelas X MIPA 3 SMA Negeri 1 manggis semester genap tahun pelajaran 2020/2021 melalui penerapan model problem based learning. Penelitian ini dilakukan dalam dua siklus pembelajaran. Obyek penelitian berupa hasil belajar dan aktivitas siswa. Untuk mengukur hasil belajar siswa digunakan tes hasil belajar siswa yang berbentuk soal obyekstif sebanyak 25 butir soal.Untuk mengukur aktivitas siswa digunakan lembar observasi aktivitas siswa yang berisikan 5 butir aktivitas yang diamati dan menggunakan pedoman penskoran skala linkert.Analisis data yang digunakan dalam penelitian ini adalah analisis deskriptif. Hasil penelitian menunjukkan penerapan model problem based learning melalui aplikasi whatsapp group dalam pembelajaran biologi dapat meningkatkan hasil belajar dan aktivitas siswa kelas X MIPA 3 SMA Negeri 1 Manggis semester genap tahun pelajaran 2020/2021. Berdasarkan hasil analisis pemberian tindakan bahwa hasil belajar siswa pada siklus I sebesar 75,4 meningkat sebesar 4,6\% menjadi 80 pada siklus II. Daya serap hasil belajar siklus I sebesar 75\% meningkat menjadi $80 \%$ pada siklus II. Ketuntasan klasikal pada siklus I sebesar $86 \%$ meningkat menjadi $94 \%$ pada siklus II. Capaian ini sesuai dengan kriteria yang keberhasilan penelitian ditetapkan yaitu rata-rata hasil belajar minimal 65 , daya serap minimal $65 \%$ dan ketuntasan klasikal minimal 85\%. Aktivitas siswa kelas X MIPA 3 SMA Negeri 1 Manggis pada semester genap tahun pelajaran 2020/2021 dapat ditingkatkan melalui penerapan model problem based learning dalam pembelajaran biologi. Pencapaian aktivitas siswa terus mengalami peningkatan hingga $78 \%$ siswa yang minimal memiliki aktivitas sangat aktif. Capaian ini sesuai dengan kriteria yang keberhasilan penelitian ditetapkan yaitu jumlah siswa memiliki aktivitas aktif minimal 85\%.Penerapan model problem based learning dalam pembelajaran biologi dapat meningkatkan hasil belajar dan aktivitas siswa, sehingga penelitian ini dapat dilanjutkan oleh peneliti lain dengan mengangkat subjek dan objek yang berbeda.
\end{abstract}

Kata kunci : model problem based learning, hasil belajar dan aktivitas siswa.

\section{ABSTRACT}

This classroom action research aims to improve the learning outcomes and activities of students of class X MIPA 3 SMA Negeri 1 Mangosteen in the even semester of the 2020/2021 school year through the application of a problem based learning model. This research was conducted in two learning cycles. The object of research is in the form of learning outcomes and student activities. To measure student learning outcomes, a test of student learning outcomes is used in the form of 25 objective questions. To measure student activity, a student activity observation sheet was used which contained 5 items of observed activity and used a linkert scale scoring guideline. The data analysis used in this study was descriptive analysis. The results showed that the application of the problem based learning model through the whatsapp group application in biology learning could improve the learning outcomes and activities of class X MIPA 3 students at SMA Negeri 1 Manggis in the even semester of the 2020/2021 school year. Based on the results of the analysis of the provision of action that student learning outcomes in the first cycle of 75.4 increased by $4.6 \%$ to 80 in the second cycle. The absorption of learning outcomes in the first cycle of $75 \%$ increased to $80 \%$ in the second cycle. Classical completeness in the first cycle of $86 \%$ increased to $94 \%$ in the second cycle. This achievement is in accordance with the criteria for which research success has been determined, namely an average learning outcome 
of at least 65, absorption of at least $65 \%$ and classical completeness of at least $85 \%$. The activities of class X MIPA 3 students of SMA Negeri 1 Manggis in the even semester of the 2020/2021 school year can be increased through the application of problem based learning models in biology learning. Achievement of student activities continues to increase up to $78 \%$ of students who at least have very active activities. This achievement is in accordance with the criteria that the success of the research has determined, namely the number of students having active activities of at least $85 \%$. The application of the problem based learning model in biology learning can improve student learning outcomes and activities, so this research can be continued by other researchers by raising different subjects and objects.

Keywords: problem based learning model, learning outcomes and student activities.

\section{PENDAHULUAN}

Pembelajaran jarak jauh atau daring dimulai sekitar tanggal 16 bulan Maret akhir 2020, di mana siswa mulai belajar dari rumahnya masing-masing tanpa perlu pergi ke sekolah. Yusuf Bilfaqih dan M. Nur Qomarudin (2015: 18) menyampaikan bahwa pembelajaran daring merupakan program penyelenggaraan kelas pembelajaran dalam jaringan untuk menjangkau kelompok target yang masif dan luas. Pembelajaran daring menggunakan jaringan internet dengan aksesibilitas, konektivitas, fleksibilitas, dan kemampuan untuk memunculkan berbagai jenis interaksi pembelajaran. Oleh karena itu, diperlukan alternatif pembelajaran untuk menunjang kualitas pembelajaran yang baik demi keberlangsungan pendidikan. Guru melakukan inovasi dalam pembelajaran di antaranya dengan memanfaatkan teknologi dalam pembelajaran seperti Whatsapp, google meet, google form, dan lain sebagainya. Selain itu, guru juga menggunakan bahan ajar dan media lainnya dalam penyampaian materi kepada siswa.

Kegiatan pembelajaran yang dilaksanakan di sekolah penulis selama semester ganjil tahun pelajaran 2020/2021 kepada kelas X MIPA3 adalah belajar daring dngan menngunakan aplikasi google formulir. Pada awalnya siswa sangat antusias untuk mengerjakan tugas, siswa sangat aktif mengirim tugas melalui google formulir namun dengan seiring berjalannya waktu siswa sudah mulai bosan belajar di rumah, hanya beberapa yang bertanya sehingga tugas yang dikumpulkan menjadi terlambat dan ada beberapa hasil pekerjaan siswa dituliskan oleh temannya atau bahkan ada yang Cuma menyontek pekerjaan temennya.

Berdasarkan hasil penilaian hasil belajar siswa secara daring dengan google formulir pada semester ganjil tahun pelajaran 2020/2021 kelas X MIPA3 diperoleh data bahwa hasil belajar siswa belum mencapai KKM seperti table 1 .

\section{Tabel 1. Rata-Rata Hasil Penilaian Harian Siswa Kelas X MIPA 3 SMA Negeri 1 Manggis}

\begin{tabular}{|c|c|}
\hline Aspek & Nilai \\
\hline Nilai Rata -Rata & 63,9 \\
\hline Daya Serap Siswa (DSS) & $51,7 \%$ \\
\hline
\end{tabular}

Berdasarkan data di atas maka perlu diadakan perbaikkan proses pembelajaran di kelas $\mathrm{X}$ MIPA 3. Sebelum diadakan perbaikan perlu dilakukan refleksi terhadap pembelajaran sebelumnya untuk perbaikan pada proses pembelajaran pada materi selanjutnya. Hasil refleksi terhadap pembelajaran sebelumnya di kelas X MIPA 3 SMA Negeri 1 Manggis tahun pelajaran 2020/2021 ditemukan beberapa permasalahan antara lain sebagai berikut ; Rendahnya rata rata penilaian harian belajar siswa secara daring dengan menggunakan aplikasi google formulir disebabkan karena siswa belum biasa menggunakan google form secara merata, konten yang disampaikan melalui google form belum bervariasi dan sangat terbatas, siswa tdak dapat melakukan tanya jawab dengan gurunya karena google formulir ini tidak dapat melakukan diskusi, dan siswa tidak dapat materi dengan media yang berbeda. 
Dalam proses pembelajaran hendaknya terjalin hubungan yang baik yang bersifat mendidik dan mengembangkan peserta didik. Guru sebagai pendidik tidak hanya menyampaikan materi akan tetapi sebagai figur yang dapat merangsang peserta didik untuk aktif berpartisipasi dalam proses pembelajaran. Sebagaimana tuntutan kurikulum yang dilaksanakan saat ini yaitu Kurikulum 2013 hendaknya menekankan pada keterlibatan siswa secara aktif. Guru harus memiliki kemampuan yang cukup sebagai pengelola dalam proses kegiatan pembelajaran. Guru yang memiliki kemampuan tersebut diharapkan dapat menciptakan suasana dan lingkungan belajar yang efektif sehingga hasil belajar yang diperoleh bisa optimal. Menurut penelitian yang dilakukan Batubara (2016), menunjukkan bahwa penggunaan google formulir dalam pembelajaran sangat baik untuk kuesionr, menginput data dan memberikan ulangan. Pemanfaatan google formulir kurang bagus untuk pemberian materi yang berisi video, power point, gambar dan diskusi. Begitu juga hasil penulisan makalah yang dilakukan oleh Wibawanto (2018) yang menunjukkan pembelajaran dengan aplikasi google formulir sedikit lebih ribet karena siswa harus memiliki alamat email, membuka tautan atau google drive dan hmtl. Keadaan ini akan menyebabkan siswa cepet bosan karena harus melalui beberapa tahapan untuk membuka tugas atau materi yang diberikan guru. Selain karena penggunaan media aplikasi secara daring kurang tepat, pembelajaran khususnya mata pelajaran biologi juga dihadapkan pada beberapa tantangan seperti : Pertama, jumlah kompetensi dasar biologi di kelas $\mathrm{X}$ sangat banyak dengan waktu yang relatif singkat (11 kompetensi dasar). Hal tersebut menyebabkan waktu belajar daring tersebut dimanfaatkan untuk transfer materi pelajaran tanpa siswa dibantu dalam pengaplikasiannya dalam menyelesaikan permasalahan. Dampaknya hasil belajar dan aktivitas belajar masih rendah. Kedua, kurangnya pemecahan masalah dan pengaplikasian konsep yang dipelajari. Selama ini, karena waktu yang terbatas siswa diminta melatih pemecahan masalah dan mengaplikasikan materi sendiri di rumah lewat pemberian tugas dan kuesioner. Siswa mengerjakan tugas tanpa bimbingan teman atau guru sehingga apabila siswa tidak paham siswa akan kesulitan dalam menyelesaikan tugasnya. Akibatnya siswa tahu konsep tetapi tidak dapat mengaplikasikannya dalam penyelesaian tugas atau permasalahan. Hal ini juga dibuktikan dengan penelitian yang dilakukan oleh Subagia et al. (2007) yang melibatkan 48 guru sains di Bali. Hasil penelitiannya menunjukkan bahwa guru hanya memahami mengajar sebagai proses pemindahan pengetahuan dari guru ke siswa. Begitu juga hasil penelitian yang dilakukan oleh Arnyana (2007) yang menunjukkan pembelajaran biologi yang dilaksanakan belum terbiasa mengkaitkan materi pelajaran dengan keadaan kehidupan sehari-hari siswa.

Berdasarkan uraian diatas, pembelajaran selama ini diterapkan memiliki karakteristik yang berbeda dengan model problem besed learning melalui Aplikasi WhatsApp Group yang akan diterapkan. Perbedaaan karakteristik ini akan menimbulkan konsekuensi pada cara dan hasil belajar yang dimiliki oleh siswa. Model problem based learning dapat mempengaruhi prestasi belajar. Penelitian yang dilakukan oleh Madiya (2012) yang menunjukkan bahwa siswa yang belajar dengan model problem based learning nmenunjukkan prestasi belajar kimia dan konsep diri siswa lebih baik dibandingkan dengan model PEEK. Sedangkan menurut Wiji Lestari (2021), dalam penelitiannya menunjukkan bahwa pemanfaatan WhatsApp group dalam pembelajaran di SD dapat meningkatkan keaktifan siswa karena WhatsApp Gorup sebagai media pembelajaran dapat. menunjang kegiatan pembelajaran dalam jaringan (Daring) dengan memanfaatkan berbagai fitur yang tersedia seperti fitur foto, video, dokumen dan video call. Untuk itu, peneliti ingin mengangkat masalah ini melalui suatu penelitian yang berjudul "Penerapan Model Problem Based Learning Melalui aplikasi whatsApp Group dalam Pembelajaran Biologi Untuk Meningkatkan Hasil Belajar dan Aktivitas Siswa Kelas X MIPA 3 SMA Negeri 1 Manggis Semester Genap Tahun Pelajaran 2020/2021. Penelitian ini bertujuan untuk meningkatkan hasil belajar siswa kelas X MIPA 3 SMA Negeri 1 Manggis Semester Genap Tahun Pelajaran 2020/2021 dengan penerapan model Problem Based Learning melaluaplikasi WhatsApp group dalam pembelajaran biologi.dan meningkatkan aktivitas siswa kelas X MIPA 3 SMA Negeri 1 Manggis Semester Genap Tahun Pelajaran 2020/2021 dengan 
penerapan model Problem Based Learning melalui aplikasi WhatsApp group dalam pembelajaran biologi.

\section{METODE PENELITIAN}

Jenis penelitian yang dilakukan adalah penelitian tindakan kelas (classroom action research) yang secara umum bertujuan meningkatkan dan memperbaiki kualitas proses pembelajaran tempat berlangsungnya penelitian (Arikunto,dkk. 2010). Tindakan yang dilakukan dalam penelitian ini adalah penerapan model pembelajaran problem based learning. Penelitian ini dilaksanakan pada kelas X MIPA3 SMA Negeri 1 Manggis semester genap Tahun Pelajaran 2020/2021. Penelitian ini dilaksanakan dalam dua siklus, masing-masing siklus dengan empat tahapan yaitu: 1) perencanaan, 2) tindakan, 3) observasi/evaluasi, dan 4) refleksi. Teknik pengumpulan data hasil belajar berupa tes hasil belajar sedangkan aktivitas siswa diukur dengan lembar observasi.

\section{HASIL DAN PEMBAHASAN}

\section{Hasil}

1. Deskripsi proses dan hasil kegiatan belajar mengajar pada siklus pertama

Setelah dilaksanakan tindakan I maka diperoleh rekapitulasi nilai hasil belajar siswa yang disajikan dalam bentuk tabel sebagai berikut:

Tabel 2 Rekapitulasi Hasil Belajar Siklus I

\begin{tabular}{|c|c|c|}
\hline Aspek Perhitungan & Hasil & Kategori \\
\hline Rata-rata & 75,4 & Tuntas \\
\hline Daya serap & $75 \%$ & Tercapai \\
\hline Ketuntasan klasikal & $86 \%$ & Tercapai \\
\hline
\end{tabular}

Berdasarkan Tabel 2 diperoleh hasil sebagai berikut nilai rata-rata hasil belajar siswa adalah 75,4 dan daya serap $75 \%$. Nilai ini sudah sesuai dengan ketuntasan yang ditetapkan yaitu minimal siswa memperoleh nilai 65 dan daya serap $65 \%$ pada pembelajaran biologi. Berdasrkan tabel 4.1 ketuntasan klasikal siswa kelas X MIPA 3 SMA Negeri 1 Manggis tahun pelajaran 2020/2021 dalam pembelajaran biologi sudah mencapai $86 \%$, hasil ini di atas ketuntasan klasikal yang ditetapkan yaitu $85 \%$. Oleh karena itu pembelajaran pada siklus I sudah berjalan secara optimal.

berjalan secara optimal.

Sebaran hasil belajar siklus I terlihat dalam bentuk tabel sebagai berikut:

Tabel 3. Sebaran Hasil Belajar Siklus I

\begin{tabular}{|c|l|c|c|}
\hline No & Kategori & Frekuensi & Presentase \\
\hline 1 & Tidak Tuntas & 5 & $14 \%$ \\
\hline 2 & Tuntas & 31 & $86 \%$ \\
\hline 3 & Jumlah & $\mathbf{3 6}$ & $\mathbf{1 0 0 \%}$ \\
\hline
\end{tabular}

Berdasarkan tabel 3 maka dapat dilihat profil sebaran hasil belajar siswa pada siklus I terlihat pada gambar 2 berikut ini : 


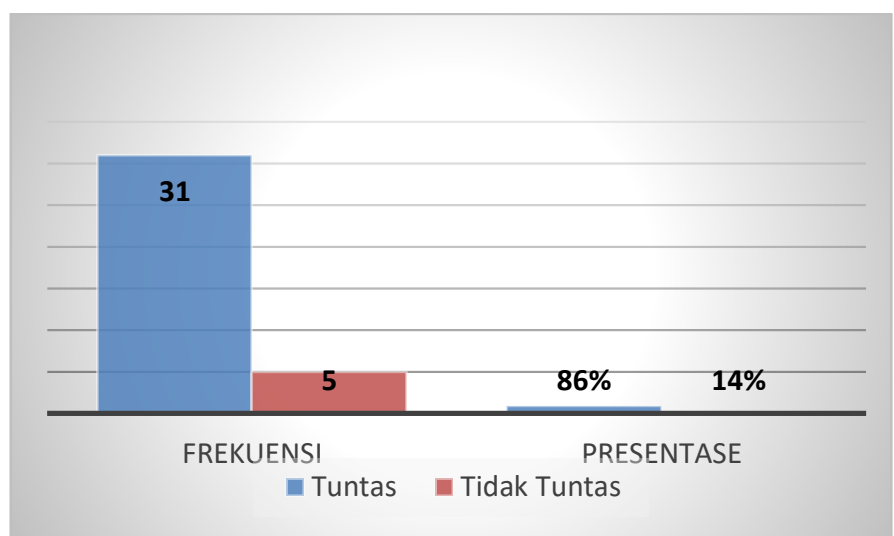

Gambar 1. Sebaran Hasil Belajar Siklus I

2. Deskripsi aktivitas belajar siklus pertama

Sebaran aktivitas siswa pada masing-masing katagori disajikan pada Tabel 5.

Tabel 4. Sebaran Aktivitas Siswa Siklus I

\begin{tabular}{|c|l|c|c|}
\hline No & Kategori & Frekuensi & Presentase \\
\hline 1 & Sangat Aktif & 17 & $47 \%$ \\
\hline 2 & Aktif & 13 & $36 \%$ \\
\hline 3 & Cukup Aktif & 6 & $17 \%$ \\
\hline 4 & Kurang Aktif & 0 & $0 \%$ \\
\hline 5 & Sangat Kurang Aktif & 0 & $0 \%$ \\
\hline 6 & Jumlah & $\mathbf{3 6}$ & $\mathbf{1 0 0 \%}$ \\
\hline
\end{tabular}

Berdasarkan tabel 4 sebaran aktivitas siswa siklus I maka dapat dilihat profil pencapaian aktivitas siswa siklus I disajikan pada Gambar 4.2 berikut ini.

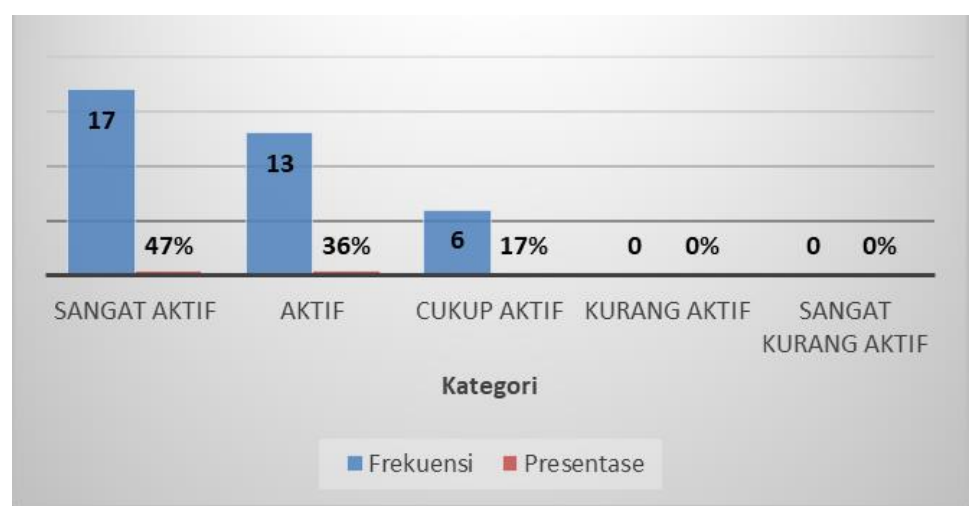

\section{Gambar 2. Sebaran Aktivitas Siswa Siklus I}

Berdasarkan Gambar 2 tampak bahwa 17\% siswa memiliki aktivitas cukup aktif, 36\% siswa memiliki aktivitas aktif, $47 \%$ siswa memiliki aktivitas sangat aktif. Secara keseluruhan aktivitas siswapada siklus I tergolong katagori aktif.

3. Deskripsi proses dan hasil kegiatan belajar mengajar pada siklus kedua

Hasil observasi yang dilaporkan pada siklus II memuat tentang hasil belajar. Setelah dilaksanakan tindakan II maka diperoleh rekapitulasi nilai hasil belajar siswa yang disajikan dalam bentuk tabel sebagai berikut:

Tabel 5. Rekapitulasi Hasil Belajar Siklus II

\begin{tabular}{|c|c|c|}
\hline Aspek Perhitungan & Hasil & Kategori \\
\hline Rata-rata & 80 & Tuntas \\
\hline Daya serap & $80 \%$ & Tercapai \\
\hline
\end{tabular}


Berdasarkan Tabel 5 diperoleh hasil sebagai berikut nilai rata-rata hasil belajar siswa adalah 80 dan daya serap $80 \%$. Nilai ini sudah sesuai dengan ketuntasan yang ditetapkan yaitu minimal siswa memperoleh nilai 65 dan daya serap $65 \%$ pada pembelajaran biologi. Berdasrkan tabel 4.4 ketuntasan klasikal siswa kelas X MIPA 3 SMA Negeri 1 Manggis tahun pelajaran 2020/2021 dalam pembelajaran biologi sudah mencapai 94\%, hasil ini di atas ketuntasan klasikal yang ditetapkan yaitu $85 \%$. Oleh karena itu pembelajaran pada siklus II sudah berjalan secara optimal.

Sebaran hasil belajar siklus II terlihat dalam bentuk Tabel 6 sebagai berikut:

Tabel 6 Sebaran Hasil Belajar Siklus II

\begin{tabular}{|c|l|c|c|}
\hline No & Kategori & Frekuensi & Presentase \\
\hline 1 & Tidak Tuntas & 2 & $6 \%$ \\
\hline 2 & Tuntas & 34 & $94 \%$ \\
\hline 3 & Jumlah & $\mathbf{3 6}$ & $\mathbf{1 0 0 \%}$ \\
\hline
\end{tabular}

Berdasarkan tabel 6 maka dapat dilihat profil sebaran hasil belajar siswa siklus II terlihat pada gambar 3 berikut ini :

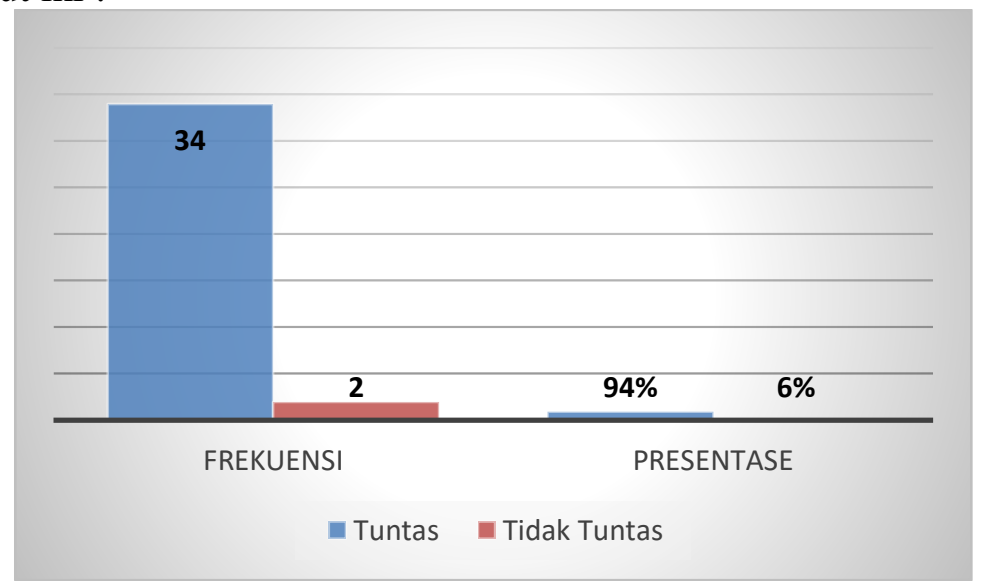

Gambar 3. Sebaran Hasil Belajar Siklus II

Berdasarkan Gambar 3 tampak bahwa hasil belajar siswa pada siklus II diperoleh 34 orang siswa hasil belajarnya kategori tuntas dengan persentase $94 \%$ tuntas

4. Deskripsi aktivitas belajar siklus II

Sebaran aktivitas siswa pada masing-masing katagori disajikan pada Tabel 6.

Tabel 6. Sebaran Aktivitas Siswa Siklus II

\begin{tabular}{|c|l|c|c|}
\hline No & \multicolumn{1}{|c|}{ Kategori } & Frekuensi & Presentase \\
\hline 1 & Sangat Aktif & 28 & $78 \%$ \\
\hline 2 & Aktif & 8 & $22 \%$ \\
\hline 3 & Cukup Aktif & 0 & $0 \%$ \\
\hline 4 & Kurang Aktif & 0 & $0 \%$ \\
\hline 5 & Sangat Kurang Aktif & 0 & $0 \%$ \\
\hline 6 & Jumlah & $\mathbf{3 6}$ & $\mathbf{1 0 0 \%}$ \\
\hline
\end{tabular}

Berdasarkan tabel 6 sebaran aktivitas siswa siklus II maka dapat dilihat profil pencapaian aktivitas siswa siklus II disajikan pada gambar 4 berikut ini. 


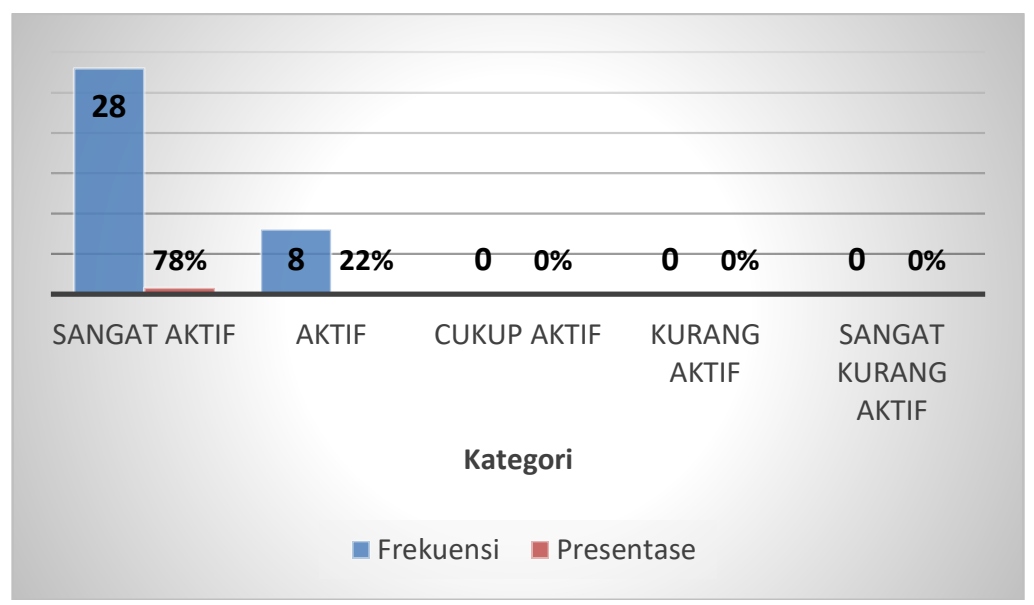

\section{Gambar 4. Sebaran Aktivitas Belajar Siklus II}

Berdasarkan Gambar 4 tampak bahwa 22\% siswa memiliki aktivitas aktif, 78\% siswa memiliki aktivitas sangat aktif. Secara keseluruhan aktivitas siswa pada siklus II tergolong katagori sangat aktif.

5. Perkembangan hasil belajar siswa sebagai berikut.

Perkembangan hasil penelitian antara siklus I dan siklus II dapat dilihat kembali pada hasil belajar siswa selama siklus I dan sikus II. Perbandingan hasil belajar siswa selama siklus I dan sikus II adalah sebagai berukut :

Tabel 7. Perkembangan Hasil Belajar Siswa

\begin{tabular}{|c|c|c|}
\hline Aspek Perhitungan & Siklus I & Siklus II \\
\hline Rata-rata & 75.4 & 80 \\
\hline Daya serap & $75 \%$ & $80 \%$ \\
\hline Ketuntasan klasikal & $86 \%$ & $94 \%$ \\
\hline
\end{tabular}

Perkembangan hasil belajar siswa dari siklus I sampai akhir siklus ke II ditampilkan dalam gambar 5 berikut.

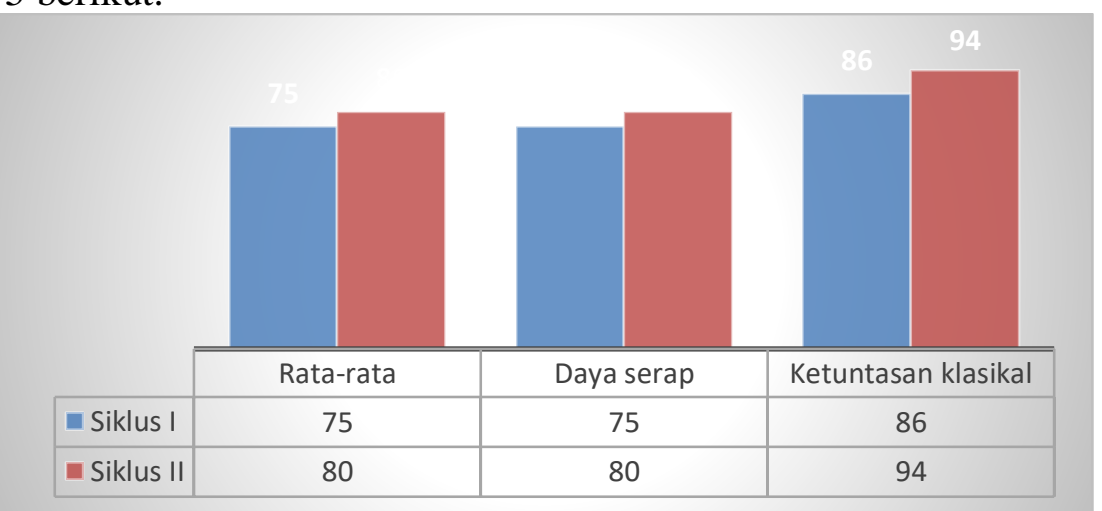

\section{Gambar 5. Perkembangan hasil belajar siswa dari siklus I sampai akhir siklus ke II}

Berdasarkan tabel 7 dan gambar 5 dapat diketahui bahwa hasil belajar siswa menunjukkan peningkatan. Hasil ini terlihat dari rata-rata hasil belajar siswa siklus I sebesar 75 meningkat menjadi 80 pada siklus II. Daya serap hasil belajar siklus I sebesar $75 \%$ meningkat menjadi $80 \%$ pada siklus II. Ketuntasan klasikal pada siklus I sebesar $86 \%$ meningkat menjadi 94\% pada siklus II. Capaian ini sesuai dengan kriteria yang keberhasilan penelitian ditetapkan yaitu rata-rata hasil belajar minimal 65 , daya serap minimal $65 \%$ dan ketuntasan klasikal minimal $85 \%$. 
6. Perkembangan aktivitas belajar siswa

Hal yang sama juga dilakukan pada aktivitas siswa. Perbandingan aktivitas siswa selama siklus I dan sikus II adalah sebagai berukut :

Tabel 8. Perkembangan Aktivitas Siswa

\begin{tabular}{|c|l|c|c|}
\hline \multicolumn{1}{|l|}{ No } & Kategori & Siklus I & Siklus II \\
\hline 1 & Sangat Aktif & $47 \%$ & $78 \%$ \\
\hline 2 & Aktif & $36 \%$ & $22 \%$ \\
\hline 3 & Cukup Aktif & $17 \%$ & $0 \%$ \\
\hline 4 & Kurang Aktif & $0 \%$ & $0 \%$ \\
\hline 5 & Sangat Kurang Aktif & $0 \%$ & $0 \%$ \\
\hline & Jumlah Rerata Skor & 19.19 & 22.75 \\
\hline & Kategori & Aktif & Sangat Aktif \\
\hline
\end{tabular}

Perkembangan aktivitas siswa dari siklus I sampai akhir siklus ke II ditampilkan dalam gambar 6 berikut.

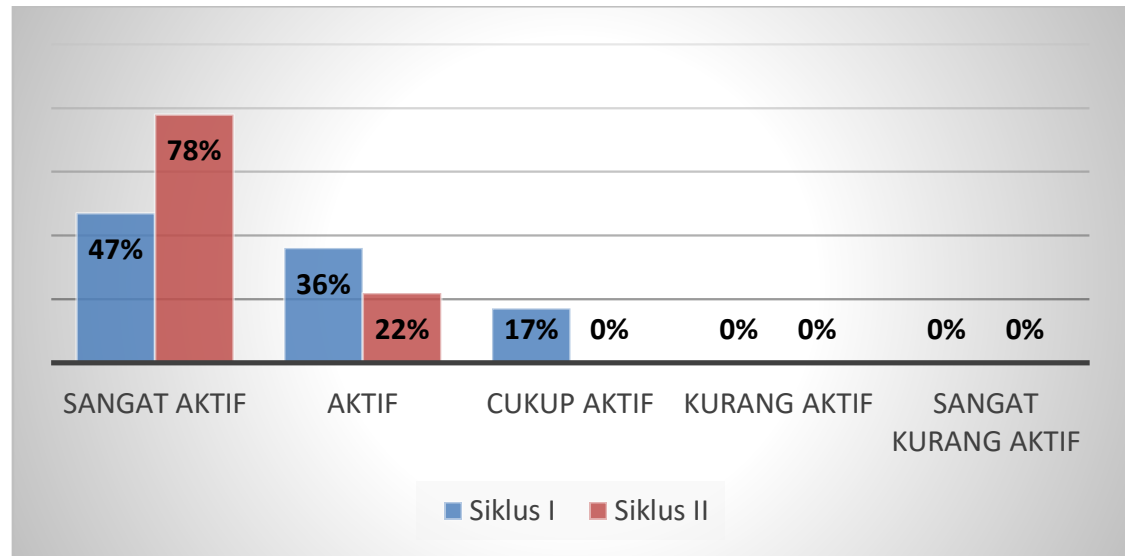

\section{Gambar 6. Perbandingan Aktivitas Bellajar Siswa Siklus I dan Siklus II}

Dari gambar 4.6 terlihat bahwa aktivitas siswa terus mengalami peningkatan hingga $78 \%$ siswa yang minimal memiliki aktivitas sangat aktif. Capaian ini sesuai dengan kriteria yang keberhasilan penelitian ditetapkan yaitu jumlah siswa memiliki aktivitas aktif minimal $85 \%$.

\section{Pembahasan}

Hasil penelitian yang peneliti lakukan selama 2 siklus menunjukkan adanya peningkatan hasil belajar dan aktivitas belajar siswa, setelah peneliti menerapkan model problem based learning secara daring. Berdasarkan hasil analisis pemberian tindakan bahwa hasil belajar siswa pada siklus I sebesar 75,4 meningkat sebesar 4,6 \% menjadi 80 pada siklus II. Daya serap hasil belajar siklus I sebesar $75 \%$ meningkat menjadi $80 \%$ pada siklus II. Ketuntasan klasikal pada siklus I sebesar $86 \%$ meningkat menjadi $94 \%$ pada siklus II. Capaian ini melampaui kriteria yang ditetapkan yaitu rata-rata hasil belajar minimal 65 , daya serap minimal $65 \%$ dan ketuntasan klasikal minimal $85 \%$.

Jika dilihat dari pencapaian aktivitas siswa terus mengalami peningkatan hingga $79 \%$ siswa yang minimal memiliki aktivitas sangat aktif. Capaian ini sesuai dengan kriteria yang keberhasilan penelitian ditetapkan yaitu jumlah siswa memiliki aktivitas aktif minimal $85 \%$.

Hasil penelitian ini memberikan gambaran bahwa penerapan model problem based learning dapat digunakan sebagai alternatif dalam meningkatkan hasil belajar dan aktivitas belajar siswa. 
Kendala atau hambatan yang ditemukan pada kasus belum mampu siswa menyesuaikan diri dengan model problem based learning. Siswa belum memahami secara menyeluruh langkah-langkah kegiatan pembelajaran yang harus mereka lakukan. Selain itu, permasalahan yang disajikan pada LKS model problem based learning adalah permasalahan kontekstual yang berbentuk soal cerita. Siswa sedikit mengalami kesulitan dalam memahami permasalahan dalam LKS tersebut. Hal ini disebabkan karena selama ini siswa lebih sering mengerjakan masalah-masalah yang sifatnya eksplisit dan teoretis, di mana semua variabel yang diketahui dan ditanyakan sudah tersedia secara jelas. Beberapa siswa juga masih sulit menghubungkan pengetahuan awal yang telah mereka miliki dengan pengetahuan baru secara mandiri untuk menyelesaikan masalah, sehingga perlu berkolaborasi dengan temannya dengan bantuan bimbingan dari guru. Selain itu, siswa juga kurang dalam mengungkapkan ide dan gagasannya untuk menanggapi permasalahan yang diajukan.

Tindakan perbaikan yang dilakukan untuk mengatasi kendala dan permasalahan yang ditemui adalah seperti yang telah dipaparkan pada hasil refleksi siklus I. Perbaikan tindakan yang dilakukan misalnya dengan memberikan bimbingan dengan lebih intensif pada siswa dalam memecahkan permasalahan dalam kelompok serta dalam diskusi awal, men yampaikan hasil kerja kelompok pada kelompok lain dalam diskusi kelas, serta memotivasi siswa agar mau mengungkapkan permasalahannya untuk di diskusikan bersama-sama.

Secara konseptual bahwa model problem based learning memiliki sejumlah keunggulan, diantaranya pembelajaran ini dilaksanakan dalam kelompok kecil yang memungkinkan siswa berinteraksi secara sosial dengan teman-teman dalam satu kelompoknya, memiliki rasa tanggung jawab dalam kerja kelompoknya, serta melalui penyelesaian masalahmasalah yang otentik yang mampu meningkatkan daya saing untuk mampu memecahkan persoalan yang diberikan. Belajar dengan model problem based learning juga dapat membangkitkan keingintahuan siswa, memberi motivasi untuk bekerja serius sampai mereka menemukan jawaban serta keterlibatan siswa secara aktif dalam proses pembelajaran.

Selain itu, model problem based learning merupakan model pembelajaran yang melibatkan metakognisi siswa. Berdasarkan Sadia (2014) bahwa problem based learning dirancang dalam suatu prosedur pembelajaran yang diawali dengan sebuah masalah sebagai pelatih metakognitif. Metakognisi merupakan pengetahuan mengenai kemampuan kognitif diri sendiri. Pelibatan metakognisi ini muncul pada fase starting new problem dan fase problem follow up. Pada fase ini, siswa akan mengumpulkan informasi dan fakta yang diistilahkan dengan "what do we know", "what do we need to know", dan "what do we need to do". Dengan melakukan hal tersebut, maka siswa akan mampu memfokuskan perhatian kepada apa yang mereka perlukan dalam memecahkan masalah, menghubungkan apa yang mereka ketahui dengan apa yang mereka perlu ketahui, berhipotesis, menguji hipotesis yang mereka ajukan lalu mengambil keputusan. Kegiatan tersebut akan berujung pada peningkatan hasil belajar siswa dan aktivitas belajar siswa.

\section{KESIMPULAN}

Berdasarkan pembahasan hasil penelitian dapat disimpulkan bahwa penerapan model pembelajaran problem based learning melalui aplikasi whatsapp group dapat meningkatkan hasil belajar dan aktivitas belajar biologi siswa kelas X MIPA3 SMAN 1 Manggis tahun pelajaran 2020/2021. Untuk lebih mengoptimalkan pelaksanaan pembelajaran secara daring perlu adanya penelitian lanjutan untuk mempersiapan PBM yang lebih bermakna.

\section{DAFTAR PUSTAKA}

Arikunto, S. (2006). Prosedur penelitian: Suatu pendekatan praktek. Jakarta: PT Asdi Mahasatya.

Arnyana, I. B. P. (2007). Penerapan Model PBL Pada Pelajaran Biologi Untuk Meningkatkan Kompetensi Dan Kemampuan Berpikir KritisS iswa Kelas X SMA Negeri 1 Singaraja 
Tahun Pelajaran 2006/2007. Jurnal Pendidikandan Pengajaran IKIP Negeri Singaraja. 40 (2), 231-251. April 2007.

Batubara, husein Hamdan.2016. Penggunaan Google Form Sebagai Alat Penilaian Kinerja Dosen. Artikel. Program Studi PGMI. Universitas Islam Kalimantan.

Lestari, Wiji. 2021. Pemanfaatan WhaysApp sebagai Media Pembelajaran dalam jaringan Masa Pandemi Covid-19 di Kelas VI SD. Skripsi. Program Studi PGSD. Jurusan PAUD dan Dasar. FKIP Universitas Jambi.

Madiya, I Wayan. (2012). Pengaruh Model pembelajaran berbasis masalah Terhadap Prestasi belajar Kimia dan Konsep diri Siswa. Artikel. Vol.2.Nomor2. Jurnal Pendidikan dan Pembelajaran IPA Indonesia Undiksha Singaraja

Permendiknas Nomor 22 Tahun 2016 tentang Standar Isi. (2006). Tersedia pada http://hfirnandopontianak.blogspot.com/.

Sadia, I W. (2014). Model-model Pembelajaran Sains Konstruktivistik. Yogyakarta: Graha Ilmu.

Subagia, I W., \& Wiratma, I G.L. (2007). Potret Pelasanaan Pembelajaran Sains pada Berbagai Jenjang Seolah di Bali. Jurnal Pendidiandan Pengajaran (JPP) Lembaga Pengembangan Pendidikan dan Pembelajaran Universitas Negeri Malang. 14 (1). $45-$ 55.

Wibawanto,Tri. (2018). Pemanfaatan Google Form sebagai media pembelajaran jarak jauh atasi penyebaran covid-19. Pengembang Teknologi pembelajaran ahli Muda. Jakarta 